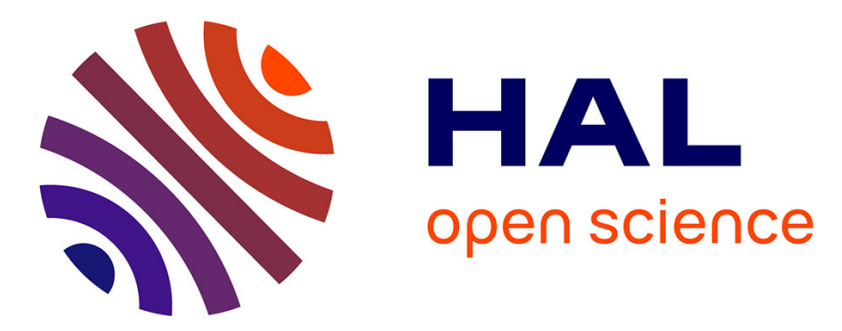

\title{
Tape Development: Microstructure and Critical Current Densities
}

R. Flukiger, G. Grasso, A. Jérémie, B. Hensel, R. Gladyshevskii, J.-C. Grivel, F. Marty, Christine Opagiste, A. Perrin, M. Däumling

\section{- To cite this version:}

R. Flukiger, G. Grasso, A. Jérémie, B. Hensel, R. Gladyshevskii, et al.. Tape Development: Microstructure and Critical Current Densities. 8th International Symposium on Superconductivity, ISS'95, Oct 1995, Hamamatsu, Shizuoka, Japan. pp.781. hal-00587240

\section{HAL Id: hal-00587240 \\ https://hal.science/hal-00587240}

Submitted on 27 Apr 2011

HAL is a multi-disciplinary open access archive for the deposit and dissemination of scientific research documents, whether they are published or not. The documents may come from teaching and research institutions in France or abroad, or from public or private research centers.
L'archive ouverte pluridisciplinaire HAL, est destinée au dépôt et à la diffusion de documents scientifiques de niveau recherche, publiés ou non, émanant des établissements d'enseignement et de recherche français ou étrangers, des laboratoires publics ou privés. 
Presented at ISS'95, Hamamatsu, Japan, 28/10 - 2/11/1995, Advances in Superconductivity, VIII, Ed. Hayakava, Enomoto, Springer, 1996, p. 781

\title{
Tảpe Development: Microstructure and Critical Current Densities
}

\author{
RENE FLÜKIGER ${ }^{1,2}$, GIOVANNI GRASSO ${ }^{1,2}$, ANDREA JEREMIE ${ }^{1}$, BERNHARD HENSEL ${ }^{1}$, \\ ROMAN GladysheVsKm ${ }^{1}$, JEAN-ClaUde GRIVEL ${ }^{1}$, FRANK MART1 ${ }^{1,2}$, CHRISTINE \\ OPAGISTE $^{2, \uparrow}$, ANTONIO PERIN $^{1}$, AND MANFRED DÄUMLING ${ }^{1, \ddagger}$ \\ ${ }^{1}$ Dépt. Phys. Mat. Cond. (DPMC), 24, quai Ernest Ansermet, CH-1211 Genève, Switzerland \\ ${ }^{2}$ Groupe Appl. Phys. (GAP), 30, rue de l'Ecole de Médecine, CH-1211 Genève, Switzerland \\ ${ }^{\dagger}$ Present address : IUT d'Annecy, 9, rue de l'Arc-en-Ciel, BP 240, F-74942 Annecy-le-Vieux, France \\ * Present address : Kernforschungszentrum, ITP, P.O.Box 3640, D-76021 Karlsruhe, Germany.
}

\begin{abstract}
The formation of the textured $\mathrm{Bi}, \mathrm{Pb}(2223)$ phase in mono- and multifilamentary tapes is described as a result of several reactions, involving an intermediate phase, $\mathrm{Bi}, \mathrm{Pb}(2212)$, which is formed as a solid solution of the initial phase $\mathrm{Bi}(2212)$, the latter having a monoclinic superstructure.

For $\mathrm{Bi}, \mathrm{Pb}(2223)$ tapes, a direct correlation between the degree of texturing of the initial $\mathrm{Bi}(2212)$ grains after rolling (before reaction) and of the current carrying $\mathrm{Bi}, \mathrm{Pb}(2223)$ platelets (after reaction) is shown. The difference between the critical current densities of pressed and rolled tapes is discussed by comparing the maximum applicable uniaxial pressure with the local pressure exerted by the rolls. The optimization of the complex preparation process leading to long, rolled $\mathrm{Bi}, \mathrm{Pb}(2223)$ tapes is discussed. The lateral distribution of the transport critical current densities in monofilamentary $\mathrm{Bi}, \mathrm{Pb}(2223)$ tapes with $\mathrm{j}_{\mathrm{c}}(77 \mathrm{~K}, 0 \mathrm{~T})=28^{\prime} 000 \mathrm{~A} / \mathrm{cm}^{2}$ shows a marked minimum at the centre and a maximum at the sides, the highest value reaching $54^{\prime} 000 \mathrm{~A} / \mathrm{cm}^{2}$. At $4.2 \mathrm{~K}$ and $14 \mathrm{~T}$, the same tape reached the value $\mathrm{j}_{\mathrm{c}}=75^{\prime} 000 \mathrm{~A} / \mathrm{cm}^{2}$.

For long $(>1 \mathrm{~m})$, rolled multifilamentary $\mathrm{Bi}, \mathrm{Pb}(2223)$ tapes with 7 and 19 cores, critical current densities up to $23^{\prime} 000 \mathrm{~A} / \mathrm{cm}^{2}$ have been obtained. The field dependence of $j_{c}$ is essentially the same as for monofilamentary tapes.

The variation of the critical current density in $\mathrm{Bi}, \mathrm{Pb}(2223)$ tapes as a function of $\mathrm{B}$ and $\mathrm{T}$ is presented and discussed within the « railway switch » model.
\end{abstract}

KEYWORDS: High $T_{c}$ superconductors, critical current density, current distribution, crystal structure

\section{INTRODUCTION}

In spite of the extraordinary metallurgical complexity of the multinary system $\mathrm{Bi}-\mathrm{Pb}-\mathrm{Sr}-\mathrm{Ca}-\mathrm{Cu}-\mathrm{O}$ in the region of the so-called $\mathrm{Bi}, \mathrm{Pb}(2223)$ phase, a substantial progress has been achieved in the last years in producing long tapes with high critical current densities. It is remarkable that the highest critical current values for long tapes were obtained by industrial manufacturers, e.g. Sumitomo (Japan) or American Superconductors or IGC (USA): this shows the importance of an extremely precise control of several fabrication parameters, e.g. powder precursors, calcination processes, deformation procedures and reaction conditions. It appears that close control is only possible if a certain number of sophisticated techniques are available. Currently, the fabrication by the « Powder-In-Tube » technique has reached a relatively high level: high critical current density values have been reported for rolled tapes: $\mathrm{j}_{\mathrm{c}}(77 \mathrm{~K}, 0 \mathrm{~T})=40^{\prime} 000 \mathrm{~A} / \mathrm{cm}^{2}$ for short lengths[1], and values close to $30^{\prime} 000 \mathrm{~A} / \mathrm{cm}^{2}$ for lengths reaching close to $100 \mathrm{~m}[2,3]$. Recently, the value of $30^{\prime} 000 \mathrm{~A} / \mathrm{cm}^{2}$ at $77 \mathrm{~K}, 0 \mathrm{~T}$ was obtained in our laboratories for monofilamentary $\mathrm{Bi}, \mathrm{Pb}(2223)$ tapes of $>0.5 \mathrm{~m}$ length [4,5]. 
We are still far from a complete understanding of these processes, out simple correlations have been established which contribute to an enhanced knowledge of the complex mechanism. Some of these correlations have been described in a recent review article [5], other correlations are more recent $[6,7]$. In addition, such fundamental elements as the crystal structure are still matter of interest.

\section{CRYSTAL STRUCTURE OF Bi(2212) and $\mathrm{Bi}, \mathrm{Pb}(2212)$}

There are several ways to start the reaction leading to $\mathrm{Bi}, \mathrm{Pb}(2223)$ : either with a precursor containing $\mathrm{Bi}(2212)$ or $\mathrm{Bi}, \mathrm{Pb}(2212)[8,9]$. However, we have found that this difference is of little importance for the reaction process: in the case of $\mathrm{Bi}, \mathrm{Pb}(2212)$, the $\mathrm{Pb}$ diffuses out at temperatures $>400^{\circ} \mathrm{C}$, so that the situation at $>800^{\circ} \mathrm{C}$ is very similar in both cases [10]. The crystal structure of both phases has been recently refined by single crystal X-Ray diffractometry [11]: it follows from Fig. 1 that $\mathrm{Bi}, \mathrm{Pb}(2212)$ can be considered as a solid solution of $\mathrm{Bi}(2212)$ because of the similar structures.

The « average » crystal structure of $\mathrm{Bi}(2212)$ is known to be orthorhombic. It has been found recently that this compound has a monoclinic, commensurable "superstructure » [11]. The enhanced precision in determining the local neighbors of each atom of the elementary cell with 135 atomic sites may be of importance for theoretical models describing the occurrence of superconductivity in these materials.

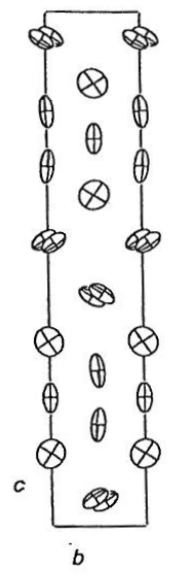

(a)

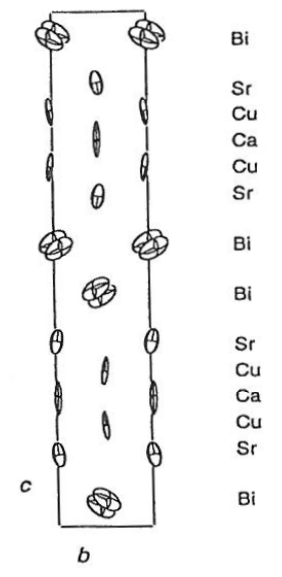

(b)

Fig. 1. Sections of the average structures a) $\mathrm{Bi}(2212)$ and b) $\mathrm{Bi}, \mathrm{Pb}(2212)$ in projections along [1 0 0]. Ref. [11].

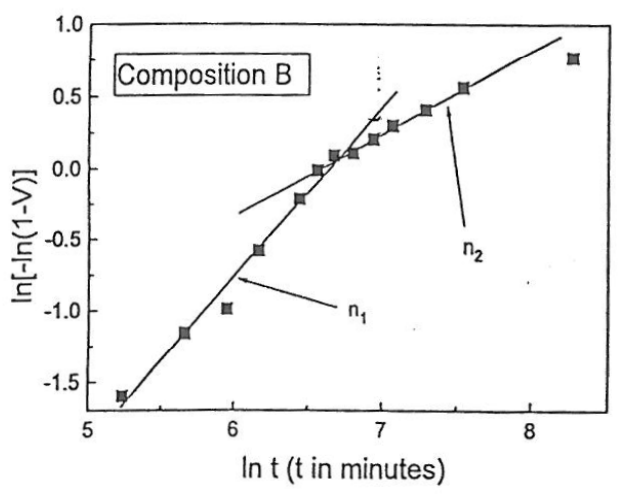

Fig. 2. Variation of $\ln [-\ln (1-\mathrm{V})]$ vs. $\ln (t)$ for pellets reacted at $857^{\circ} \mathrm{C}$, where $\mathrm{V}$ is the volume of $\mathrm{Bi}, \mathrm{Pb}(2223)$ phase [12].

THE REACTION KINETICS FROM Bi(2212) to Bi,Pb(2223)

The reaction from $\mathrm{Bi}(2212)$ to $\mathrm{Bi}, \mathrm{Pb}(2223)$ can be described by a two-step reaction: it starts with a relatively rapid grain growth of $\mathrm{Bi}, \mathrm{Pb}(2212)[10]$, which is completed within $<30$ hours. During this time, $\mathrm{Pb}$ atoms partially substitute the $\mathrm{Bi}$ atoms, while the ratio of the elements with respect to each other is thus of a different stoichiometry. The formation of $\mathrm{Bi}, \mathrm{Pb}(2212)$ starts immediately after reaching the reaction temperature $\left(830-840^{\circ} \mathrm{C}\right.$ inside a $\mathrm{Ag}$ sheath), as can be deduced from the change 
of the lattice parameters measured on samples neated a tew minutes only. During the first 10 hours of reaction, a growth of the $\mathrm{Bi}, \mathrm{Pb}(2212)$ grains from $\sim 1$ to $>30 \mu \mathrm{m}$ is observed. As a consequence of the $\mathrm{Bi}, \mathrm{Pb}(2212)$ grain growth, the amount of liquid is continuously decreasing, which was confirmed by performing DTA measurements of the tapes after various reaction times at $840^{\circ} \mathrm{C}$ [12].

The first traces of $\mathrm{Bi}, \mathrm{Pb}(2223)$, observed by $\mathrm{X}$-Ray diffraction, are only observed after a few hours. This period corresponds to the time needed for the $\mathrm{Bi}, \mathrm{Pb}(2212)$ phase to reach a certain critical composition of the solid solution, above which it becomes unstable.

The further transformation to $\mathrm{Bi}, \mathrm{Pb}(2223)$ still contains some unresolved points, and several models have been advanced how to get from a two-layer to a three-layer configuration, but none of them gives a satisfactory picture. A detailed TEM analysis is needed in order to solve this problem.

We have recently studied the kinetics of the $\mathrm{Bi}, \mathrm{Pb}(2223)$ phase formation by plotting the variation of the exponent $\mathrm{n}$ of the Avrami equation for isothermal transformations as a function of time. For a series of different compositions, a kink in the curve $\ln [-\ln (1-V)]$ vs. $\ln (t)$ was found (Fig. 2) after approximately 12 hours of reaction [12] ( $\mathrm{V}$ is the volume fraction of the $\mathrm{Bi}, \mathrm{Pb}(2223)$ phase as determined from $\mathrm{X}$-Ray diffraction). The value $n_{1}=1.5$ in Fig. 2 for times $<12$ hours is interpreted as the formation and beginning of growth of $\mathrm{Bi}, \mathrm{Pb}(2223)$ crystallites from the germ nuclei formed at the beginning of the process. The value $\mathrm{n}_{2}=0.85$ after $\mathrm{t}>12$ hours reflects the $\mathrm{Bi}, \mathrm{Pb}(2223)$ grain growth (a value of $\mathrm{n}=1$ would correspond to a pure 2D growth). The formation of grain boundaries - the decisive mechanism for the critical current densities - occurs well after 12 hours.

\section{CRITICAL CURRENT DENSITIES}

The variation of $j_{c}$ vs. $\mathrm{B}$ at $77 \mathrm{~K}$ for $\mathrm{Bi}, \mathrm{Pb}(2223)$ tapes is shown in fig 3 for a monofilamentary tape of $0.5 \mathrm{~m}$ length [4].

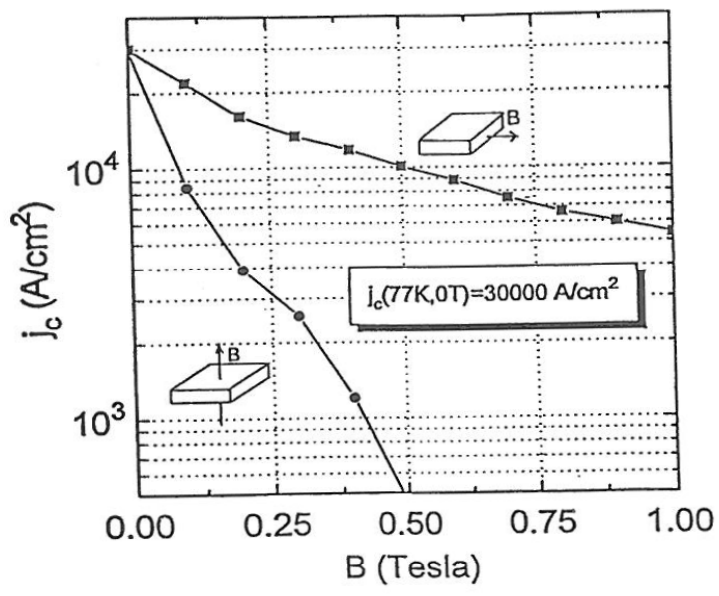

Fig.3. $\mathrm{j}_{\mathrm{c}}$ vs. $\mathrm{B}$ at $77 \mathrm{~K}$ for a rolled $\mathrm{Bi}, \mathrm{Pb}(2223)$ tape.

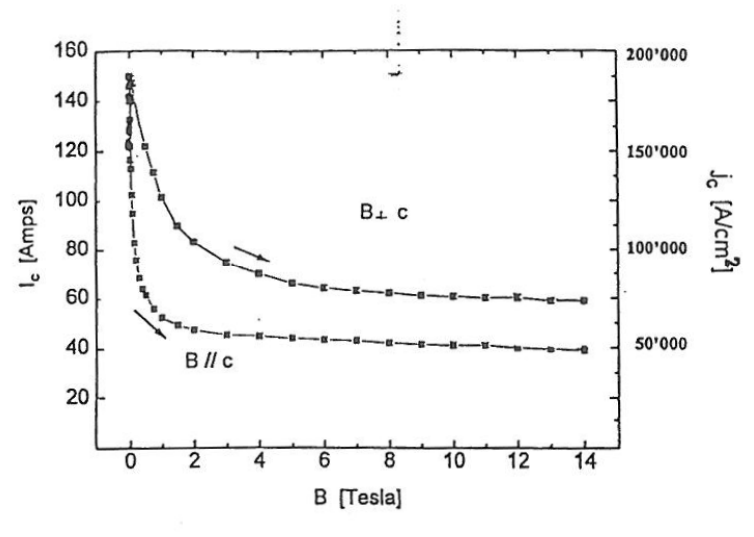

Fig.4. $\mathrm{j}_{\mathrm{c}}$ vs. B at $4.2 \mathrm{~K}$ for the same tape as in Fig.3.

The anisotropy as well as the field dependence are not essentially different from those of ref.1, with $\mathrm{j}_{\mathrm{c}}(77 \mathrm{~K}, 0 \mathrm{~T})=40^{\prime} 000 \mathrm{~A} / \mathrm{cm}^{2}$. This indicates that the essential difference between these tapes is mainly due to a larger number of strongly coupled grain boundaries in the tape with higher $\mathrm{j}_{\mathrm{c}}$, the current carrying mechanism being unchanged. The corresponding variation of $j_{\mathrm{c}}$ vs. B at $4.2 \mathrm{~K}$ for our tape with $\mathrm{j}_{\mathrm{c}}(77 \mathrm{~K}, 0 \mathrm{~T})=30^{\prime} 000 \mathrm{~A} / \mathrm{cm}^{2}$ is shown in Fig.4, from which a value of $\mathrm{j}_{\mathrm{c}}(4.2 \mathrm{~K}, 25 \mathrm{~T}) \approx 70^{\prime} 000 \mathrm{~A} / \mathrm{cm}^{2}$ can be extrapolated. A comparison with a large number of tapes confirms that it is possible to estimate the value of $j_{c}$ at $4.2 \mathrm{~K}$ and very high fields (e.g. $25 \mathrm{~T}$ ) for $\mathrm{B} / / \mathrm{a}, \mathrm{b}$ once the value $\mathrm{j}_{\mathrm{c}}(77 \mathrm{~K}, 0 \mathrm{~T}$ ) is known. 
Recently, a correlation was found between the degree of texturing of the $\mathrm{Bi}(2212)$ grains in a tape after deformation (before heat treatment) and the properties of the $\mathrm{Bi}, \mathrm{Pb}(2223)$ tape after the reaction heat treatment [4], as shown by Figs. 5 and 6 . The texture of $\mathrm{Bi}(2212)$ grains is determined by X-ray diffraction analysis, and is defined by the parameter

$$
f=\frac{I(115)}{I(115)+I(008)} \text {. }
$$

From Fig. 5, it can be seen that $f$ is smallest at the end of deformation, which means highest degree of texturing. After reaction, texturing in the region close to the oxide/Ag interface increases due to the internal pressure exerted by the growing grains, and another way of defining the degree of texturing has to be used. In Fig. 6 , the effective transport misalignment angle $\Phi_{e}$ as defined by angle dependent $j_{c}$ measurements [13] has been plotted as a function of tape thickness. A comparison between Figs. 5 and 6 allows to establish a correlation between the texturing of $\mathrm{Bi}(2212)$ grains and the texturing of the $\mathrm{Bi}, \mathrm{Pb}(2223)$ which carry the current.

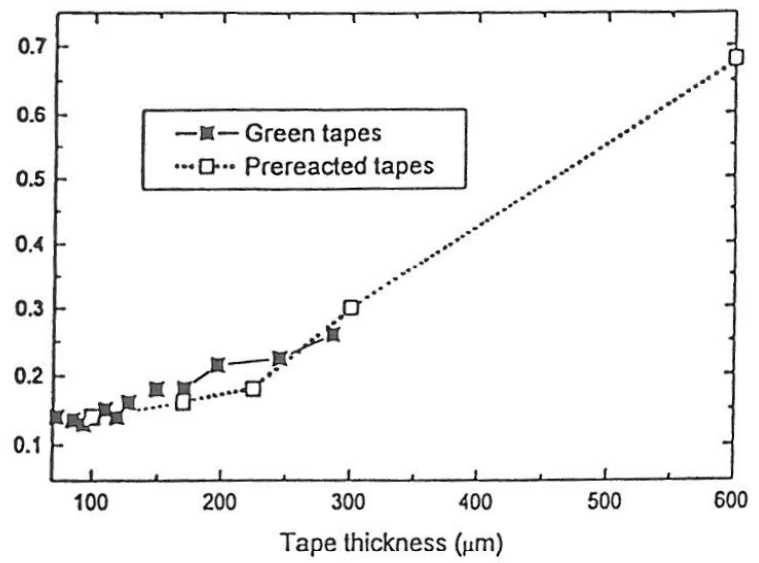

Fig.5. Variation with tape thickness of the degree of texturing of the unreacted $\mathrm{Bi}(2212)$ after deformation.

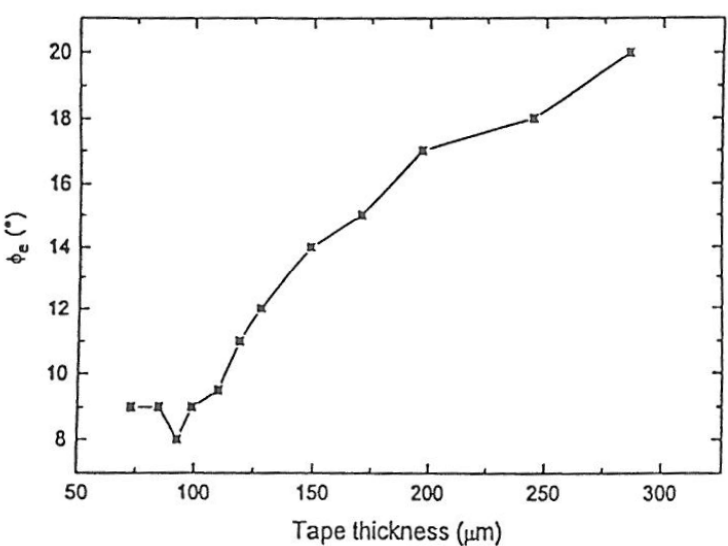

Fig.6. Correlation between tape thickness and effective transport misalignment angle, $\Phi_{\mathrm{e}}[4]$.

Another question related to the deformation process is why $\mathrm{j}_{\mathrm{c}}$ of $\mathrm{Bi}, \mathrm{Pb}(2223)$ tapes produced by pressing is generally higher than for rolled tapes. An answer has been given recently [7], comparing the forces acting on the tape during deformation. As shown in Fig.7, $\mathrm{j}_{\mathrm{c}}$ increases monotonically for pressures up to $>2 \mathrm{GPa}$, while for rolled tapes, a sharp decrease is observed above $0.6 \mathrm{GPa}$ [7]. This can be explained by the formation of cracks in transversal direction because of the higher elongation during the rolling process.

\section{CURRENT DISTRIBUTION}

The lateral transport current distribution in monofilamentary $\mathrm{Bi}, \mathrm{Pb}(2223)$ tapes was determined by the strip-cutting technique [14] and is shown in Fig. 8 for two tapes prepared by the rolling procedure with $\mathrm{j}_{\mathrm{c}}(77 \mathrm{~K}, 0 \mathrm{~T})=22^{\prime} 000$ and $28^{\prime} 000 \mathrm{~A} / \mathrm{cm}^{2}$, respectively. 


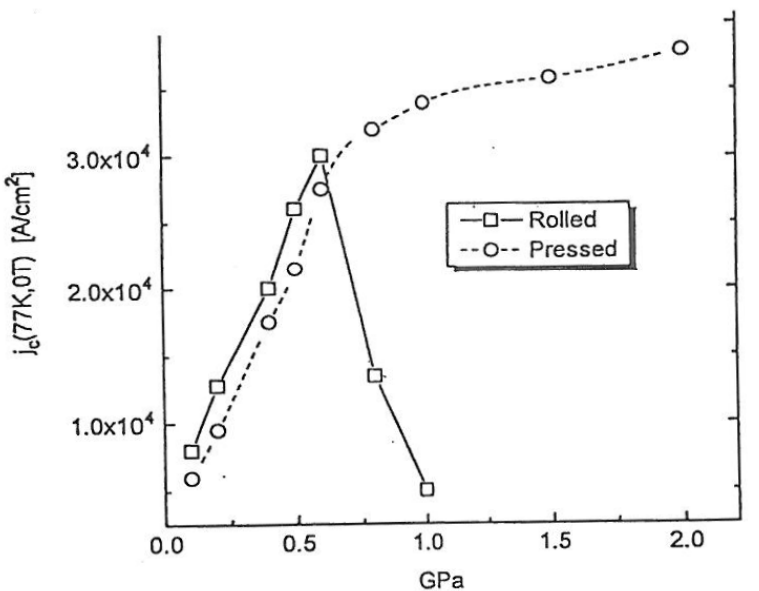

Fig.7. $\mathrm{j}_{\mathrm{c}}$ of pressed and rolled $\mathrm{Bi}, \mathrm{Pb}(2223)$ tapes as a function of the effective pressure during deformation [7].

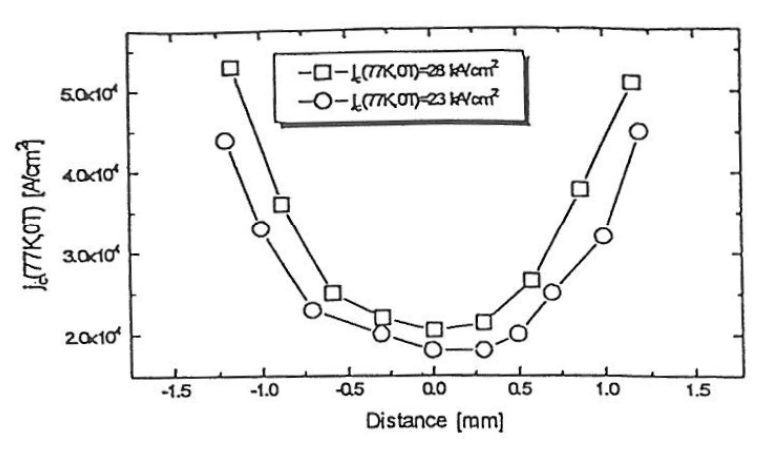

Fig. 8. Lateral $\mathrm{j}_{\mathrm{c}}$ distribution for two $\mathrm{Bi}, \mathrm{Pb}(2223)$ tapes with different $j_{\mathrm{c}}$ values [14].

It has been found that the critical current density at the sides is considerably higher than at the centre, the maximum transport $\mathrm{j}_{\mathrm{c}}$ at the sides being $54^{\prime} 000 \mathrm{~A} / \mathrm{cm}^{2}$ [14]. This distribution was confirmed on the same samples by non-invasive Hall probe measurements [15] and by magneto-optical imaging [16]. Several reasons lead to the observed "parabolic" behavior of $j_{c}: a$ ) a higher compression of the oxide layer is observed at the sides, b) a larger amount of foreign phases is observed at the centre of the tape, and c) the degree of texturing at the inner centre of the tape is lower than at the sides [14].

\section{MULTIFILAMENTARY TAPES}

The cross-section of a 19 core $\mathrm{Bi}, \mathrm{Pb}(2223)$ tape is shown in Fig.9, at the end of the drawing process (diameter $1.25 \mathrm{~mm}$ ) and after rolling to $0.18 \mathrm{~mm}$ thickness. The superconductor ratio was 0.18 . The critical current density at $77 \mathrm{~K}, 0 \mathrm{~T}$ was $23^{\prime} 000 \mathrm{~A} / \mathrm{cm}^{2}$, which corresponds to an overall $\mathrm{j}_{\mathrm{c}}$ of $4^{\prime} 140 \mathrm{~A} / \mathrm{cm}^{2}$. The variation of $j_{c}$ vs. B measured at $70 \mathrm{~K}$ is shown in Fig. 10. The decrease between $B=0$ and $1 \mathrm{~T}$ is somewhat smaller than for the monofilamentary tapes (Fig. 3), but this is due to the lower temperature, $\mathrm{T}=70 \mathrm{~K}$.

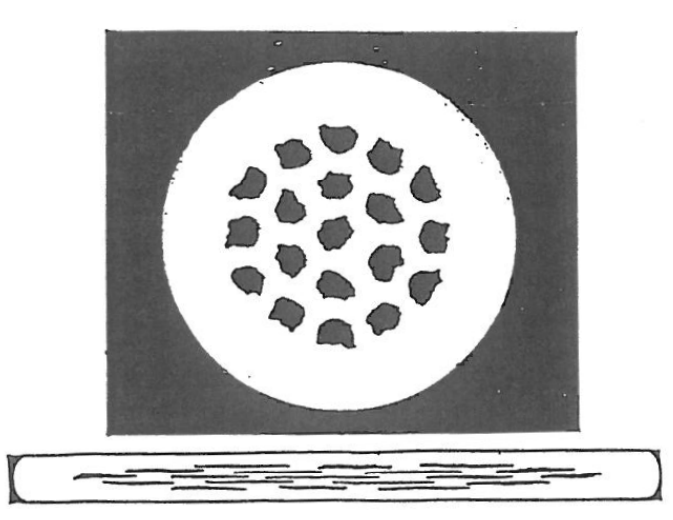

7ig. 9 Cross-section of a 19 core $\mathrm{Bi}, \mathrm{Pb}(2223)$ tape (wire diameter $1.25 \mathrm{~mm}$ and tape thickness $0.18 \mathrm{~m})$.

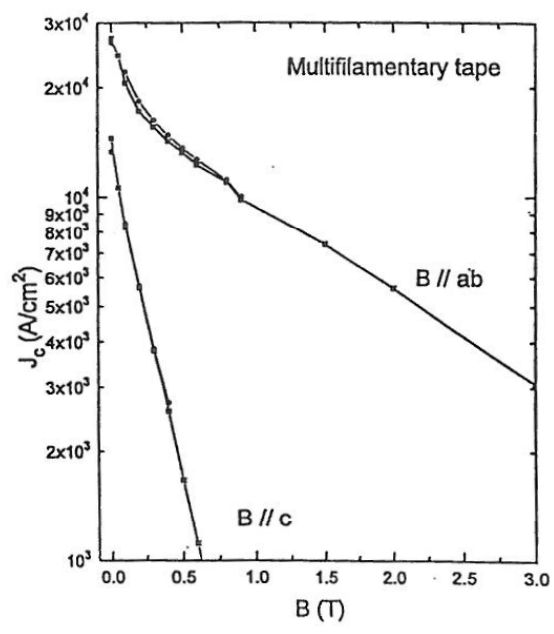

Fig.10. $\mathrm{j}_{\mathrm{c}}$ vs.B of a 19 core $\mathrm{Bi}, \mathrm{Pb}(2223)$ tape at $70 \mathrm{~K}$. 
After correcting the temperature difference, there is no noticeable difference between the variation $j_{c}(B)$ of our mono- and multifilamentary tapes, in agreement with Ref. 1 . The smaller $\mathrm{j}_{\mathrm{c}}$ value, $23^{\prime} 000$ with respect to $30^{\prime} 000 \mathrm{~A} / \mathrm{cm}^{2}$ for monofilamentary tapes is attributed to fluctuations of the individual filament cross-sections along the tape. It is to expect that an improvement of the regularity of the filament crosssection will lead to very similar $j_{0}$ values as for monofilamentary tapes.

\section{CURRENT TRANSFER IN Bi,Pb(2223) TAPES}

The current transfer from one $\mathrm{Bi}, \mathrm{Pb}(2223)$ grain to another has been recognized as occurring through small-angle c-axis tilt grain boundaries [17]. Due to the anisotropic nature of the $\mathrm{Bi}, \mathrm{Pb}(2223)$ structure and to the textured microstructure inside a tape, a detailed consideration of the current transport requires a careful definition of the various components. A model for the current transfer between $\mathrm{Bi}, \mathrm{Pb}(2223)$ platelets requires necessarily the occurrence of current densities $j^{c}{ }_{0}$ along the $c$-axis. These currents are required to distribute the net a-b plane current also in the bulk of the grain. From a direct measurement of the resulting critical current density $\mathrm{j}_{\mathrm{c}}^{\mathrm{n}}$ perpendicular to the tape surface as a function of the applied field, it was concluded that the value of the intragrain critical current density $\mathrm{j}_{\mathrm{c}}^{\mathrm{c}}$ is the main limiting factor [17]. Another important factor influencing the overall value of $j_{\mathrm{c}}$ is the total number of strongly coupled connections ("railway switches") transferring the current inside the tape.

\section{REFERENCES:}

[1] K.Sato, K.Ohkura, K.Hayashi, M.Ueyama, J.Fujikami, T.Kato presented at the Intl.Workshop on Advanced High Magnetic Fields, Febr. 20-22, 1995, Tsukuba (Japan).

[2] K.Sato, J.O.M. August 1995, p.65.

[3] G.N.Riley Jr., D.R.Parker, C.J.Christophson, P.K.Miles, J.J.Pickett, S.E.Highson, J.D.Schreiber, A.Polyanskii, D.C.Larbalestier, Proceedings for the M²S-HTSC-IV, Grenoble, France, July 1994.

[4] G.Grasso, A.Perin, R.Flükiger, Physica C (1995) 250 : 43.

[5] R.Flükiger, G.Grasso, B.Hensel, M.Däumling, R. Gladyshevskii, A.Jeremie, J.-C.Grivel, A.Perin Bismuth-based High Temperature Superconductors. Eds. H.Maeda and K. Togano, to be published.

[6] G.Grasso, F.Marti, A.Jeremie, A.Perin, B.Hensel, R.Flükiger, presented at EUCAS Conference, 4-6 July 1995, Edinburgh (U.K.).

[7] G.Grasso, A.Jeremie, R.Flükiger acepted for publication in Physica C.

[8] S.E.Dorris, B.C.Prorok, M.T.Lanagan, S.Sinha, R.B.Poeppel, Physica C (1993) $212: 66$.

[9] A.Jeremie, G.Grasso, R.Flükiger, presented at EUCAS Conf. 4-6 July 1995, Edinburgh (U.K.).

[10] A.Jeremie, J.-C.Grivel, R.Flükiger, Physica C (1994) 235-240 : 943.

[11] R. Gladyshevskii, R.Flükiger, accepted for publication in Acta Cryst.

[12] J.C.Grivel, R.Flükiger, submitted to Journal of Alloys and Compounds.

[13] B.Hensel, J.C.Grivel, A.Jeremie, A.Perin, A.Pollini, R.Flükiger, Physica C (1993) 205 : 329.

[14] G.Grasso, B.Hensel, A.Jeremie, R.Flükiger, Physica C (1995) 241: 45. and G.Grasso, B.Hensel, A.Jeremie, R.Flükiger, presented at EUCAS Conf. 4-6 July 1995, Edinburgh (U.K.).

[15] M.D.Johnston, J.Everett, M.Dhallé, G.Grasso, R.Flükiger, M. Yang, C.R.M.Grovenor, A.D.Caplin, presented at EUCAS Conf. 4-6 July 1995, Edinburgh (U.K.).

[16] D.Larbalestier, X.Y.Cai, H.Edelman, M.B.Field, Y.Feng, J.Parrell, A.Pashitski, A.Polyanskii, J.O.M. December 1994 p.20.

[17] B.Hensel, G.Grasso, R.Flükiger, Phys. Rev. (1995) B51 : 15456. 